\title{
The Effect of Herbicides on the Egyptian Broomrape (Orobanche aegyptiaca) in Tomato Fields
}

\author{
Ibrahim Ghannam, Mohammad Al-Masri, Radwan Barakat
}

Faculty of Agriculture, Hebron University, Hebron, Palestine.

Email: *radwanb@hebron.edu

Received June $16^{\text {th }}, 2011$; revised August $20^{\text {th }}, 2011$; accepted November $3^{\text {rd }}, 2011$

\begin{abstract}
The Egyptian broomrape (Orobanche aegyptiaca Pers.) is an obligate holoparasitic weed that causes severe damage to many important vegetable and field crops. In this investigation, three herbicides; chlorsulfuron, triasulfuron and imazaquin were tested to evaluate their efficiency in controlling the tomato broomrape. The herbicides significantly reduced the broomrape parasitizing tomato plants growing in pots, irrigated open field and under greenhouse conditions as foliar spray at the concentrations $\left(0.5-10 \mu \mathrm{g} \cdot \mathrm{ml}^{-1}\right)$ without visible injury effect on the plants. In the pot experiments, triasulfuron increased the dead spikes from $77 \%$ to $84 \%$; chlorsulfuron from $51 \%$ to $84 \%$ and imazaquin from $52 \%$ to $84 \%$ at the concentrations $\left(0.5-5 \mu \mathrm{g} \cdot \mathrm{ml}^{-1}\right)$ compared with the control. In the irrigated open field experiment, the herbicides were less efficient in controlling the broomrape. The dead spikes increased from $10.5 \%$ to $29.1 \%$ at the concentrations $\left(1-5 \mu \mathrm{g} \cdot \mathrm{ml}^{-1}\right)$ compared with the control. In the greenhouse experiment, the herbicides were more effective than open field and the dead spikes were increased from $30 \%$ to $68 \%$ at the concentrations 5 and $10 \mu \mathrm{g} \cdot \mathrm{ml}^{-1}$. In conclusion, the foliar application of herbicides were able to increase the broomrape dead spikes attached to the tomato plants at the concentrations $\left(3-5 \mu \mathrm{g} \cdot \mathrm{ml}^{-1}\right)$ without visible negative effect on tomato plants.
\end{abstract}

Keywords: Orobanche aegyptiaca; Chlorsulfuron; Triasulfuron; Imazaquin; Broomrape and Tomato

\section{Introduction}

The broomrape (Orobanche spp.) are obligate holoparasitic weeds that cause severe damage to the most important vegetable and field crops in the Mediterranean region and the Middle East [1]. Annual food crop losses due to broomrape infestation are estimated at about $\$ 1.3$ to 2.6 billion. Egyptian broomrape (O. aegyptiaca) together with branched broomrape (O. ramosa) infests about 2.6 million ha of solanaceous crops mainly in the Mediterranean area, North Africa, and Asia [2-4]. In Palestine, broomrape is listed as one of the most harmful weeds and poses a major constraint to crop production. The control of broomrapes is often difficult for various reasons and numerous control strategies have been tested over the years, with limited effectiveness. The control methods investigated have included changes in agricultural practices such as hand weeding, tillage, deep inversion, crop rotation, trap and catch crops, fertilization and soil solarization $[1,5-8]$ as well as chemical and biological means [3,9-20]. The chemical control of broomrapes included soil fumigation and herbicide application. Soil fumigation with methyl bromide effectively controlled

\footnotetext{
${ }^{*}$ Corresponding author.
}

broomrape [18]. Several herbicides were used to control broomrape, but selectivity to the host plant remained the main obstacle. Chlorsulfuron applied at $5 \mathrm{~g} \cdot \mathrm{a} \cdot \mathrm{i} \cdot \mathrm{h}^{-1}$ gave $100 \%$ control of emerged broomrape shoots and underground attachments and completely prevent parasite development in tomato [21]. The herbicides rimsulfuron and sulfonylurea effectively controlled O. aegyptiaca in pots, but in drip-irrigated tomatoes fields, O. aegyptiaca control was poor [11]. The best results for Orobanche control in potato was obtained by applications of rimsulfuron at $12.5 \mathrm{~g} \cdot \mathrm{a} . \mathrm{i} \cdot \mathrm{h}^{-1}$ followed by three sequential foliar applications of glyphosate at $100 \mathrm{~g} \cdot \mathrm{a} \cdot \mathrm{i} \cdot \mathrm{h}^{-1}$ [17]. Split application of low rates of imazamethapyr applied on toma- to foliage or chemigated via sprinkler irrigation achieved excellent $O$. aegyptiaca control throughout the growing season, but caused premature loss of flowers and early ripening of fruits [20].

During the last few decades, the herbicidal groups showed promising results in broomrape control; sulfonylurea, imidazolinone, and other inhibitors of the enzyme acetolactate synthase (ALS) or acytohydroxy acid synthase (AHAS) are some examples. Members of these groups showed some degree of selectivity to broomrape host plants [3,10,14-16]. Chlorsulfuron, pronamide and 
pendimethalin at $2.44 \mathrm{~g} \cdot \mathrm{a} . \mathrm{i} \cdot \mathrm{h}^{-1}$ effectively controlled Orobanche ramosa by over $98 \%$ and was the least phototoxic to tomato plants [3]. Imazaquin at about $80 \mathrm{~g} \cdot \mathrm{h}^{-1}$ and chlorsulfuron at about $6 \mathrm{~g} \cdot \mathrm{h}^{-1}$ applied as pre-emergence treatments were also active, but their performance was likely to be affected by soil conditions [14]. Glyphosate, controlled Orobanche when applied at a low rate of 50 $\mathrm{g} \cdot \mathrm{a} \cdot \mathrm{i} \cdot \mathrm{h}^{-1}$ in carrot and celery [20]. The objective of this study was to evaluate the effect of the foliar sprays of Glean, (75\% WG chlorsulfuron) a product of DU PONT DE NEMOURS Co., Amber (75\% WG triasulfuron), a product of CTS Co., and Scepter (180 g. ${ }^{-1}$ SL imazaquin) a product of AGAN, in controlling broomrape in tomato.

\section{Materials and Methods}

\subsection{Herbicides}

Three herbicides, Glean (75\% WG chlorsulfuron), Amber (75\% WG triasulfuron) and Scepter (180 g/1 SL imazaquin) were evaluated for their efficiency in controlling broomrape in tomato fields.

\subsection{Effect of the Herbicides on Broomrape and Tomato Seeds Germination}

The effect of herbicides on germination of both broomrape and tomato seeds was evaluated in Petri plates containing Whatman GF/A Glass Microfiber filter paper (Whatman International, Maidstone, UK) and in the presence of the stimulator compound GR24 at the concentration $\left(5 \mu \mathrm{g} \cdot \mathrm{ml}^{-1}\right)$. The broomrape seeds in tea bags were surface sterilized by dipping them in $70 \%$ ethanol for $30 \mathrm{sec}$. and then in 1\% sodium hypochlorite containing $0.05 \%$ Tween 20 for $10 \mathrm{~min}$. The seeds were then washed for $10 \mathrm{~min}$. in sterile water for three successive times and dried. The dried seeds were dispersed uniformly on filter paper previously moistened with $5 \mathrm{ml}$ of the GR24 solution. Tomato seeds were surface sterilized as mentioned above and 20 seeds were dispersed uniformly in Petri dishes. Five $\mathrm{ml}$ of each concentration (1, 2, 5, 7, and $10 \mu \mathrm{g} \cdot \mathrm{ml}^{-1}$ ) of the three herbicides were added to each dish. The experimental design was completely randomized with five replicates (Petri dishes). The Petri dishes were incubated at $25^{\circ} \mathrm{C}$ for 7 days. The germination of both seeds was evaluated under a stereomicroscope (Olympus SZX16).

\subsection{Effect of the Herbicides on Tomato Plants}

The effect of herbicides on tomato plants was evaluated before and after the flowering stage. Forty-day old tomato seedlings were transplanted in $4 \mathrm{~L}$ pots containing clay soil. Plants were grown in a greenhouse at $25^{\circ} \mathrm{C}$, and fertigated as necessary. The tomato plants were divided into two groups, the first group was used after six weeks from transplantation before the flowering stage; the plants were sprayed with the herbicides, trisulfuron, chlorsulfuron and imazaquin, each at the concentrations of $\left(0,1,3\right.$ and $\left.5 \mu \mathrm{g} \cdot \mathrm{ml}^{-1}\right)$. The second group of tomato plants (eight weeks old) were sprayed with the herbicides at the same concentrations mentioned above. The experimental design was completely randomized with five replicates per each concentration for each herbicide for both plant groups. Plants were sprayed with 50 $\mathrm{ml} \cdot$ plant $^{-1}$ of herbicide suspensions, while the control treatment plants were sprayed with water; plants were sprayed again after three days. Plant's fresh weights and symptoms of herbicide's injuries were recorded after three weeks.

\subsection{Effect of Herbicides on Broomrape}

The evaluation of herbicides on broomrape was evaluated in tomatoes grown in pots, open field, and greenhouse.

\subsubsection{Effect of Herbicides on Broomrape in Tomatoes Growing in Pots}

A preliminary experiment was first conducted, where forty day old tomato seedlings were transplanted in $4 \mathrm{~L}$ pots. The pots were filled with $O$. aegyptiaca infested clay soil prepared by mixing $40 \mathrm{mg}$ of Orobanche seeds per $1 \mathrm{~kg}$ air-dried soil in a cement mixer. Plants were then grown in greenhouse at $25^{\circ} \mathrm{C}$, and fertigated as necessary. After 60 days, from transplantation and when broomrape spikes were observed above soil level, the tomato plants were sprayed with the three herbicides, each at the concentrations of $(0,10,20,30,40$ and 50 $\left.\mu \mathrm{g} \cdot \mathrm{ml}^{-1}\right)$. According to the results of the preliminary experiment, a second experiment was conducted, considering the lowest herbicide concentrations effective against broomrape $\left(0,1,3\right.$, and $\left.5 \mu \mathrm{g} \cdot \mathrm{ml}^{-1}\right)$ and at the same timing mentioned above. The experimental design was completely randomized with five replicates per each concentration for each herbicide. Plants were sprayed with the herbicides suspension $\left(50 \mathrm{ml} \cdot\right.$ plant $\left.^{-1}\right)$ at the flowering stage while the control treatment plants were sprayed with water; the spraying process was repeated after two weeks. The number and weight of total spikes, dead spikes, and viable spikes were recorded after 4 weeks from last spray treatment. In addition, tomato plants foliage fresh and dry weights were determined at the end of experiment. The experiment was repeated using further lower herbicide concentrations $\left(0,0.5,1,3\right.$, and $\left.5 \mu \mathrm{g} \cdot \mathrm{ml}^{-1}\right)$ to confirm the lowest herbicide concentration effective against the parasite and at the same time safe for tomato plants. 


\subsubsection{Effect of Herbicides on Broomrape in Open Field and Greenhouse Grown Tomatoes}

Experiments were carried out at two sites in the Dura area, $10 \mathrm{~km}$ south of Hebron-Palestine. The open field at the first site had naturally uniform, heavy infestation of O. aegyptiaca. The field was transplanted with tomato (var. Niamey 1684). The plants were grown in rows (140 $\times 50 \mathrm{~cm})$ and drip irrigated. The completely randomized design of the experiment included application of the herbicides, triasulfuron, chlorsulfuron and imazaquin at the concentrations $\left(0,1,3\right.$, and $\left.5 \mu \mathrm{g} \cdot \mathrm{ml}^{-1}\right)$ with three replicates (plots) for each concentration and herbicide. Each plot had 3 rows $\times 4 \mathrm{~m}$ length, and 8 plants per row (24 plants per plot), and one row was dedicated as a border line for each plot. Two months, after planting tomatoes and when the broomrape spikes appeared above the soil surface, the tomato plants were sprayed with the herbicides at the rate of $100 \mathrm{ml}$ per plant at the concentrations mentioned earlier; the control treatment plants were sprayed with tap water. The number and weight of total spikes, dead spikes, and viable spikes were recorded after three weeks. The experiment of the second site was carried out in a commercial greenhouse which had naturally uniform and heavy infestation of O. aegyptiaca as well. The greenhouse was transplanted with tomato (var. FA 144) which was grown in rows $(120 \times 50 \mathrm{~cm})$ and drip irrigated. The completely randomized design of the experiment included three replicates (plots) per each of the concentrations $\left(0,5\right.$, and $\left.10 \mu \mathrm{g} \cdot \mathrm{ml}^{-1}\right)$ of the herbicides. Each plot had three rows $\times 4$ m length, and 7 plants per row (21 plants per plot) and one row was dedicated as a border line for each plot. After 12 weeks, and when the broomrape spikes uniformly appeared above the soil surface, the tomato plants were sprayed with $200 \mathrm{ml} \cdot \mathrm{plant}^{-1}$ of the above mentioned concentrations. The number and weight of total spikes, dead spikes, and viable spikes of the parasite and tomato plant heights were recorded after three weeks from the spray treatments.

\section{Statistical Analysis}

Data of the experiments were statistically analyzed using one-way analysis of variance (ANOVA), and Fishers LSD test $(\mathrm{P} \leq 0.05)$ was used for mean separations (Sigma Stat ${ }^{\mathbb{B}} 2.0$ program, SPSS Inc., USA).

\section{Results}

Preliminary results showed that the herbicides, chlorsulfuron, triasulfuron and imazaquin were effective against broomrape of tomato plants as a foliar spray even at the lowest concentration $\left(10 \mu \mathrm{g} \cdot \mathrm{ml}^{-1}\right.$ a.i). In addition, herbicides at these concentrations had no effect on the tomato plants treated at all stages (before and after flowering) (Figure 1). The three herbicides significantly reduced broomrape seed germination in Petri dishes at concentrations ranging from 1 to $10 \mu \mathrm{g} \cdot \mathrm{ml}^{-1}$ without significant variation between the herbicides and its concentrations. At the same time, the herbicides had not affected the tomato seed germination at concentrations below $7 \mu \mathrm{g} \cdot \mathrm{ml}^{-1}$, while reduced the germination significantly at $10 \mu \mathrm{g} \cdot \mathrm{ml}^{-1}$ (Figure 2). Furthermore, the herbicides significantly $(\mathrm{P} \leq$ $0.05)$ killed the emerging broomrape spikes attached to tomato plants grown in pots at the concentrations $(0.5$ - 5 $\left.\mu \mathrm{g} \cdot \mathrm{ml}^{-1}\right)$. Triasulfuron increased the dead spikes over the control by $77 \%-84 \%$; chlorsulfuron by $51 \%-84 \%$ and imazaquin by $52 \%-84 \%$ at the concentration range of $0.5-5 \mu \mathrm{g} \cdot \mathrm{ml}^{-1}$, respectively (Figure 3(a)). In addition, the three herbicides increased the dead broomrape spikes attached to tomato plants under greenhouse conditions; triasulfuron, chlorsulfuron, and imazaquin increased the dead spikes (\%) by 30 and 51; 60 and 68; 30 and 61 at the concentrations 5 and $10 \mu \mathrm{g} \cdot \mathrm{ml}^{-1}$, respectively (Figure 3(c)). Furthermore, the herbicides significantly $(\mathrm{P} \leq 0.05)$ increased the dead spikes percent in tomato open field when compared with the control (Figure 3(b)); triasulfuron increased the dead spikes by $10.5 \%-26.6 \%$; chlor sulfuron by $13.6 \%-29.1 \%$ and imazaquin by $13.1 \%$ -

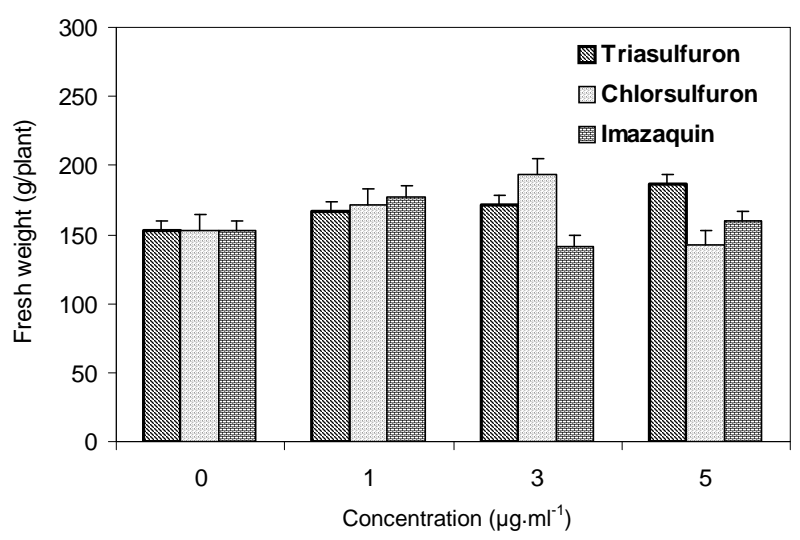

(a)

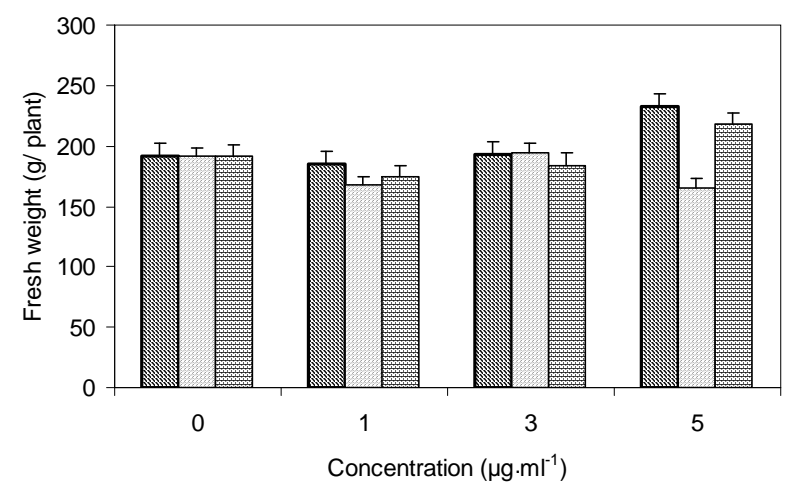

(b)

Figure 1. Effect of herbicides (chlorsulfuron, triasulfuron, and imazaquin) on fresh weights of tomato plants grown in pots treated before (a) and after the flowering stage (b). 


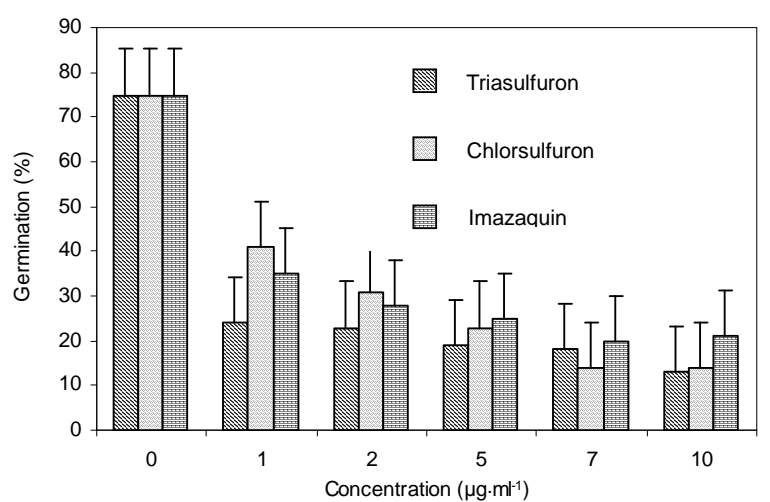

(a)

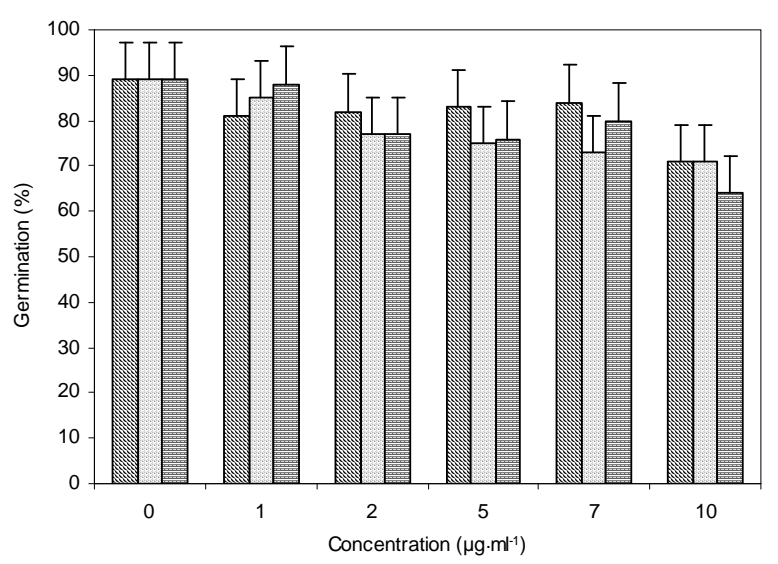

(b)

Figure 2. Effect of herbicides (triasulfuron, chlorsulfuron, and imazaquin) on broomrape seed germination (\%) in Petri dishes containing GFA filter papers and $5 \mu \mathrm{g} \cdot \mathrm{ml}^{-1}$ GR $_{24}$ (a) and on tomato seed germination (\%) in Petri dishes (b).
$28.9 \%$ at the concentrations $1-5 \mu \mathrm{g} \cdot \mathrm{ml}^{-1}$, respectively, over the control. In a nutshell, results revealed that the tested herbicides can be used effectively in reducing the tomato broomrape in the open field, in pots, and greenhouse at the concentrations $3-5 \mu \mathrm{g} \cdot \mathrm{ml}^{-1}$ as a foliar spray without visible effect on the plants. In respect to the effect of herbicides on plant's growth, the three herbicides have not negatively affected fresh weights of tomatoes grown in pots compared to the control, and only imazaquin at $5 \mu \mathrm{g} \cdot \mathrm{ml}^{-1}$ reduced the tomato fresh weight (Table 1). However, despite the fact that triasulfuron and imazaquin have not affected plant's growth under the greenhouse condition, chlorsulfuron reduced plant's growth (height by $8 \%$ and the leaves curled at the concentrations above $5 \mu \mathrm{g} \cdot \mathrm{ml}^{-1}$ ) (Table 2 ).

\section{Discussion}

All three herbicides (chlorsulfuron, triasulfuron and imazaquin) caused significant reduction of broomrape of tomato plants growing in pots at the concentrations $(0.5$ $5 \mu \mathrm{g} \cdot \mathrm{ml}^{-1}$ ) used as a foliar spray (Figure 3(a)). The herbicides at these concentrations had no effect on tomato plant's fresh weights in pots and on germination of seeds. Significant variation in herbicides effect on broomrape in the pot experiment was evident having triasulfuron the most efficient in controlling broomrape. In addition, there was a high correlation between the broomrape dead spike percent and the herbicides concentrations. Herbicides as well, reduced the broomrape seeds germination. Similar results were obtained by Qasem [3] who showed that chlorsulfuron application at $2.44 \mathrm{~g} \cdot($ a.i. $) \cdot \mathrm{ha}^{-1} \mathrm{com}-$ pletely prevented broomrape when mixed with soil prior

Table 1. Effect of herbicides on tomato plants fresh and dry weights, and roots fresh weights growing in pots.

\begin{tabular}{|c|c|c|c|c|c|}
\hline \multirow{2}{*}{ Herbicide } & \multicolumn{5}{|c|}{ Concentration $\left(\mu \mathrm{g} \cdot \mathrm{ml}^{-1}\right)$} \\
\hline & $\mathbf{0}$ & 0.5 & 1 & 3 & 5 \\
\hline & \multicolumn{5}{|c|}{ Tomato plants fresh weights $\left(\mathrm{g} \cdot\right.$ plant $\left.^{-1}, \mathrm{LSD}=18.2\right)$} \\
\hline Chlorsulfuron & $170 \mathrm{ab}$ & $170 \mathrm{ab}$ & $171 \mathrm{ab}$ & $200 \mathrm{a}$ & $192 \mathrm{a}$ \\
\hline Triasulfuron & $170 \mathrm{ab}$ & $152 \mathrm{bc}$ & 188 a & $212 \mathrm{a}$ & $195 \mathrm{a}$ \\
\hline \multirow[t]{2}{*}{ Imazaquin } & $170 \mathrm{ab}$ & $168 \mathrm{ab}$ & $151 b c$ & $161 \mathrm{~b}$ & $146 \mathrm{c}$ \\
\hline & \multicolumn{5}{|c|}{ Tomato plants dry weights $\left(\mathrm{g} \cdot\right.$ plant $\left.^{-1}, \mathrm{LSD}=4.2\right)$} \\
\hline Chlorsulfuron & $28.9 \mathrm{~b}$ & $28.9 \mathrm{~b}$ & $29.1 \mathrm{ab}$ & $34 \mathrm{ab}$ & $32.7 \mathrm{ab}$ \\
\hline Triasulfuron & $28.9 \mathrm{~b}$ & $25.9 \mathrm{~b}$ & $32.1 \mathrm{ab}$ & $36 \mathrm{a}$ & $33.2 \mathrm{ab}$ \\
\hline \multirow[t]{2}{*}{ Imazaquin } & $28.9 \mathrm{~b}$ & $28.7 \mathrm{~b}$ & $25.8 \mathrm{bc}$ & $27.2 \mathrm{bc}$ & $25 \mathrm{bc}$ \\
\hline & \multicolumn{5}{|c|}{ Tomato roots fresh weights $\left(\mathrm{g} \cdot \mathrm{plant}^{-1}, \mathrm{LSD}=6.5\right)$} \\
\hline Chlorsulfuron & $45 \mathrm{ab}$ & $48.8 \mathrm{ab}$ & $47.5 \mathrm{ab}$ & $47.5 \mathrm{ab}$ & $48.8 \mathrm{ab}$ \\
\hline Triasulfuron & $45 \mathrm{ab}$ & $55 \mathrm{ab}$ & $52.5 \mathrm{ab}$ & $60 \mathrm{a}$ & $53.4 \mathrm{ab}$ \\
\hline Imazaquin & $45 \mathrm{ab}$ & $46.3 \mathrm{ab}$ & $37.5 \mathrm{c}$ & $42.5 \mathrm{bc}$ & $38.8 \mathrm{bc}$ \\
\hline
\end{tabular}




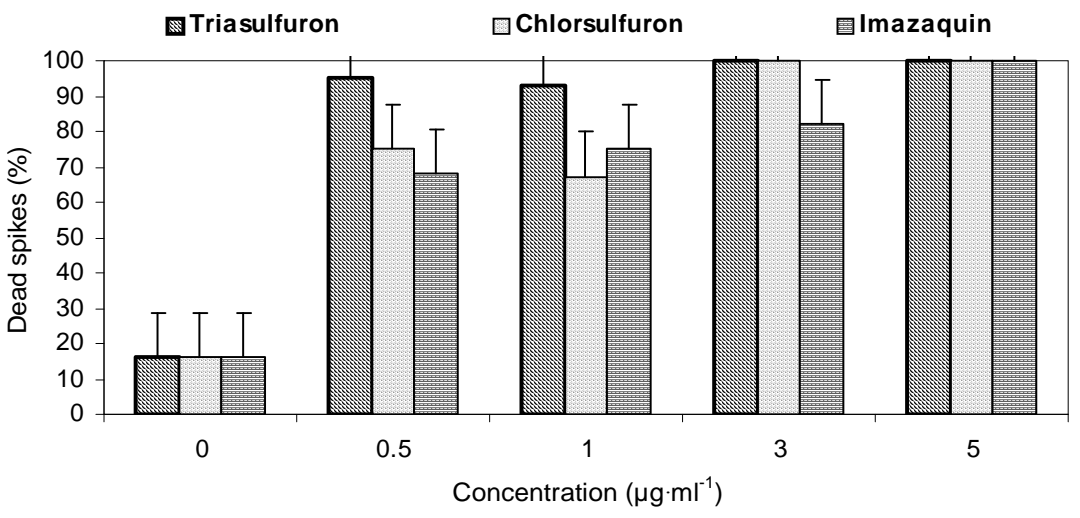

(a)

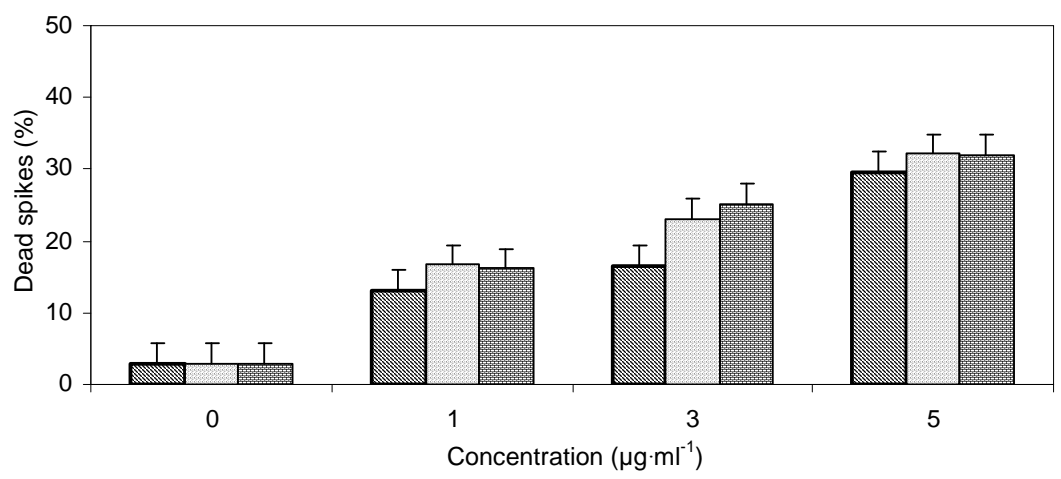

(b)

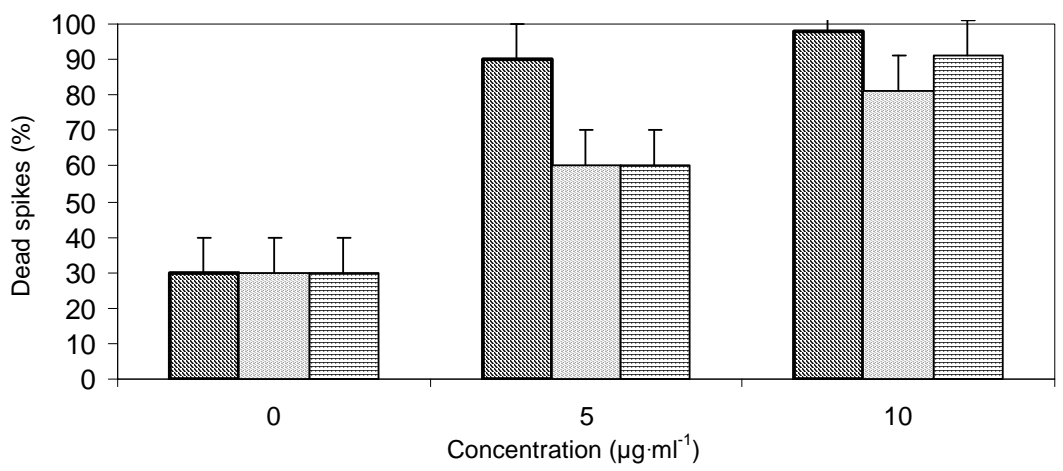

(c)

Figure 3. Effect of chlorsulfuron, triasulfuron and imazaquin on broomrape dead spikes emergence within tomato plants growing in pots (a), irrigated open field (b) and under greenhouse conditions (c) applied after 2 months from transplanting seedlings.

to tomato transplanting and a single application of chlorsulfuron at $9.75 \mathrm{~g} \cdot(\mathrm{a} . \mathrm{i}.) \cdot \mathrm{ha}^{-1}$ at $3-4$ weeks after emergence. Treatments reduced broomrape infestation and increased tomato growth compared with the control. In addition, Hershinhorn et al., [13] reported that chlorsulfuron applied at $5.0 \mathrm{~g} \cdot\left(\right.$ a.i.) $\cdot \mathrm{ha}^{-1}$ gave $100 \%$ control of broomrape spikes and underground attachments, showing that under certain conditions this herbicide may completely prevent the parasite development. In irrigated tomatoes grown in the open field, the three herbicides showed significant selective control of broomrape at the concentrations $1-5 \mu \mathrm{g} \cdot \mathrm{ml}^{-1}$ applied as a foliar spray without visible impact on the plants. It was noted, however, that the percentages of dead spikes in the open field were much lower than in pots. This might be due to the wide distribution of roots in the open field soil, plant's vigor, and herbicide mobility. In addition, percentages of dead spikes were positively correlated with increasing 
Table 2. Effect of herbicides on tomato plant heights (cm) grown in greenhouse.

\begin{tabular}{cccc}
\hline \multirow{2}{*}{ Herbicides } & \multicolumn{3}{c}{ Concentration $\left(\boldsymbol{\mu g} \cdot \mathbf{m l}^{-1}\right)$} \\
\cline { 2 - 4 } & $\mathbf{0}$ & $\mathbf{5}$ & $\mathbf{1 0}$ \\
\hline Triasulfuron & $180^{*} \mathrm{a}$ & $175 \mathrm{a}$ & $175 \mathrm{a}$ \\
Chlorsulfuron & $180 \mathrm{a}$ & $174 \mathrm{a}$ & $175 \mathrm{a}$ \\
Imazaquin & $180 \mathrm{a}$ & $186 \mathrm{a}$ & $184 \mathrm{a}$ \\
\hline
\end{tabular}

*Means followed by the same letter in a column or row are not significantly different according to Fisher LSD test $(\mathrm{P} \leq 0.05)$.

herbicide concentrations (triasulfuron $\left(\mathrm{r}^{2}=0.95\right)$, chlorsulfuron $\left(r^{2}=0.98\right)$, and imazaquin $\left.\left(r^{2}=0.98\right)\right)$. Similar results were obtained by Kotoula-Syca, [21] who reported that under field conditions, chlorsulfuron applied at $10 \mathrm{~g} \cdot \mathrm{ha}^{-1}$ (a.i.), reduced broomrape emergence by $88 \%$. In addition, Garcia-Torres et al., [14] showed that imazaquin and chlorsulfuron applied to broad bean open field at $40-80 \mathrm{~g} \cdot \mathrm{ha}^{-1}$ (a.i.) and $6 \mathrm{~g} \cdot \mathrm{ha}^{-1}$ (a.i.), respectively, considerably reduced the number of broomrape spikes and their dry weights. Additionally, Hershinhorn et al., [13] showed that chlorsulfuron and triasulfuron applied directly to soil planted with tomato seedlings by sprinkler chemigation, controlled broomrape without phytotoxic effect on tomato plants. Goldwasser et al. [22], however mentioned that a single application of triasulfuron at $7.5 \mathrm{~g} \cdot \mathrm{ha}^{-1}$ (a.i.) sprayed on potato foliage, effectively controlled broomrape but at the same time, severely damaged the crop. At the greenhouse level, triasulfuron, chlorsulfuron, and imazaquin controlled broomrape of tomatoes at the concentrations 5 and $10 \mu \mathrm{g} \cdot \mathrm{ml}^{-1}$. Triasulfuron and imazaquin showed no negative effect on tomato plants. On the other hand, chlorsulfuron reduced tomato plant's growth (height by $8 \%$ and leaves curled at the concentrations above $5 \mu \mathrm{g} \cdot \mathrm{ml}^{-1}$ ). In addition, the percentages of dead broomrape spikes in treated greenhouse were higher than those in the open field. This might be due to the higher concentrations of herbicides applied, greenhouse growth factors and broomrape sensitivity under such growth conditions. This study revealed that chemical control of broomrape (Orobanche aegyptiaca) on tomato can be achieved by using the herbicides, glean (75\% WG chlorsulfuron), amber (75\% WG triasulfuron) and scepter (180 g/L SL imazaquin). All were able to kill efficiently emerging spikes of broomrape attached to tomato plants growing in pots, open field and greenhouse at the concentrations $\left(3-5 \mu \mathrm{g} \cdot \mathrm{ml}^{-1}\right)$ when applied as a foliar spray without visible negative effect on tomato plants.

\section{REFERENCES}

[1] C. Parker and C. R. Riches, "Parasitic Weeds of the World:
Biology and Control," CAB International, University of Arizona Press, Wallingford, 1993, p. 322.

[2] A. Boari, M. Vurro, M. A. Abouzeid and M. C. Zonno, "Evidente Microbes and Microbial Products for Biological Control of Parasitic Weeds," International Bioherbicide Group Workshop, Canberra, 2003, p. 6.

[3] J. R. Qasem, "Chemical Control of Branched Broomrape (Orobanche ramosa) in Glasshouse Grown Tomato," Crop Protection, Vol. 17, No. 8, 1998, pp. 625-630. doi:10.1016/S0261-2194(98)00062-3

[4] N. Zehhar, M. Ingouff, D. Bouta and A. Fer, "Possible Involvement of Gibberellins and Ethylene in Orobanche ramosa Germination," Weed Research, Vol. 42, No. 6, 2002, pp. 464-469. doi:10.1046/j.1365-3180.2002.00306.x

[5] B. D. Acharya, G. B. Khattri, M. k. Chettri and S. C. Srivastava, "Effect of Brassica campestris var. Toria as a Catch Crop on Orobanche aegyptiaca Seed Bank," Crop Protection, Vol. 21, No. 7, 2002, pp. 533-537. doi:10.1016/S0261-2194(01)00137-5

[6] B. E. Abu-Irmaileh, "Soil Solarization Controls Broomrapes (Orobanche spp.) in Host Vegetable Crops in the Jordan Valley," Weed Technology, Vol. 5, No. 3, 1991, pp. 575-581.

[7] J. H. Westwood and C. L. Foy, "Influence of Nitrogen on Germination and Early Development of Broomrape (Orobanche spp.)," Weed Science, Vol. 47, No. 1, 1999, pp. 2-7.

[8] M. A. Haidar and M. M. Sidahmed, "Elemental Sulfur and Chicken Manure for the Control of the Branched Broomrape (Orobanche ramosa)," Crop Protection, Vol. 25, No. 1, 2006, pp. 47-51. doi:10.1016/j.cropro.2005.03.022

[9] C. L. Foy, J. Rakesh and R. Jacobsohn, "Recent Approaches for Chemical Control of Broomrape (Orobanche spp.)," Reviews in Weed Science, Vol. 4, 1989, 123-152.

[10] D. Plakhine, Y. Goldwasser, J. Hershenhorn and Y. Kleifeld, "Effect of Sulfonylurea Herbicides on Early Development Stages of Orobanche aegyptiaca," In: M. T. Moreno, J. I. Cubero, D. Berner, D. M. Joel, L. J. Musselman and C. Parker, Eds. Advances in Parasitic Plant Research. Proceeding of 6th International Parasitic Weed Symposium, Cordoba, 1996, pp. 716-725.

[11] H. Reinke, A. Rosenzweig, K. M. Clausm, C. Chisholm and P. Jensen, "Experimental Sulfonylurea Herbicide for Potatoes," Proceedings of the Brighton Crop Protection Conference of Weeds, Brighton, 18-21 November1991, pp. 445-451.

[12] I. M. Ghannam, R. M. Barakat and M. I. Al-Masri, "Biological Control of Broomrape (Orbanche aegyptica) Using Fusarium spp.," Phytopathologia Mediterranea, Vol. 46, 2007, pp. 177-184.

[13] J. Hershenhorn, Y. Goldwasser, D. Plakhine, J. H. Westwood, C. L. Foy and Y. Kleifeld, "Effect of Sulfonylurea Herbicides on Early Development of Egyptian Broomrape (Orobanche aegyptiaca) in Tomato," Weed Technology, Vol. 12, No. 1, 1998, pp. 108-114.

[14] L. Garcia-Torres and F. Lopez-Granados, "Control of Broomrape (Orobanche crenata) in Broad Beans (Vicia faba) 
with Imidazolinones and Other Herbicides," Weed Research, Vol. 31, No. 4, 1991, pp. 227-235. doi:10.1111/j.1365-3180.1991.tb01762.x

[15] L. Garcia-Torres, F. Lopez-Granados and M. CastejónMuñoz, "Pre-Emergence Herbicides for the Control of Broomrape (Orobanche cernua Loefl.) in Sunflower (Helianthus annus L.)," Weed Research, Vol. 34, No. 6, 1995, pp. 395-402. doi:10.1111/j.1365-3180.1994.tb02035.x

[16] L. Garcia-Torres, M. Jurado-Exposito, M. Casejon-Munoz and F. Lopez-Granados, "Herbicide-Treated Crop Seeds for Control of Orobanche spp.," In: J. I. Cubero, D. Berner, D. M. Joel, L. J. Musselman and C. Parker, Eds., Advances in Parasitic Plant Research. Proceedings of Sixth International Parasitic Weed Symposium, Cordoba, 16-18 November 1996, pp. 669-706.

[17] M. A. Haidar, M. M. Sidahmed, R. Darwish and A. Lafta, "Selective Control of Orobanche ramosa in Potato with Rimsulfuron and Sub-Lethal Doses of Glyphosate," Crop Protection, Vol. 24, No. 8, 2005, pp. 743-747. doi:10.1016/j.cropro.2005.01.005

[18] R. H. Burnhard, "Orobanche spp. (Biology, Damage and Control, Yield Loss Prediction Based on Quantitative Estimation of Parasites Seeds in the Soil)," Master's Thesis,
The Royal Veterinary and Agricultural University, Copenhagen, 1995.

[19] R. Jacobsohn and D. Levy, "Glyphosate for Orobanche Control in Various Crops: Problems and Promises," In: S. J. Terborg, Ed., Proceedings of Workshop on Biology and Control of Orobanche, Wageningen, 13-17 Jaunary 1986, pp. 172-175.

[20] Y. Kleifeld, Y. Goldwasser, D. Plakhine, G. Herzlinger, S. Golan and J. Hershenhorn, "Selective Control of Orobanche spp. with imazamethapyr," In: K. Wegman, L. J. Musselman and D. M. Joel, Eds., Current Problems of Orobanche Researches. Proceedings of the Fourth International Orobanche Workshop. Institute for Wheat and Sunflower, Albena, 1998, pp. 359-365.

[21] E. Kotoula-Syka, "Parasitic Plant Management in Sustainable Agriculture," Joint Meeting of WG 1+3, Sofia, 2002.

[22] Y. Goldwasser, H. Eizenberg, J. Hershenhorn, D. Plakhine, T. Blumenfeld, H. Buxbaum, S. Golan and Y. Kleifeld, "Control of Orobanche aegyptiaca and Orobanche ramose in Potato," Crop Protection, Vol. 20, No. 5, 2001, pp. $403-410$ 